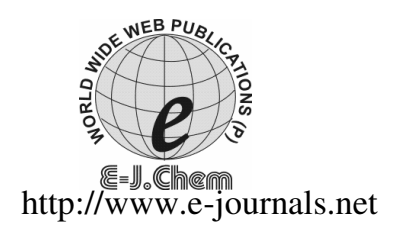

ISSN: 0973-4945; CODEN ECJHAO

E-Journal of Chemistry 2011, 8(1), 319-325

\title{
Synthesis of Glucose Based Water Soluble Molecular Tweezers as Molecular Recognition Scaffolds
}

\author{
LALIT SHARMA \\ Department of Applied Chemistry \\ Shaheed Bhagat Singh College of Engg \& Tech., Ferozepur-152 004, India \\ s.lalit@lycos.com
}

Received 3 May 2010; Accepted 18 July 2010

\begin{abstract}
Dry heating of 4,4'-methylenedianiline and $N, N^{\prime}$-dimethyl-4,4'methylenedianiline with 5,6 -anhydro-1,2-o-isopropylidene- $\alpha$-D-glucofuranose afforded molecular tweezers having tertiary amino group linked to C-6 of the glucose moiety. These molecular tweezers on deprotection with dilute acid yielded water soluble analogs which were explored for the solubilization of neutral arenes viz. naphthalene, biphenyl, durene, fluorene, anthracene and phenanthrene in acidic aqueous medium. These solid liquid extraction studies revealed that 6,6'-(N,N'-dimethyl-4", 4"'--methylenedianilino) bis ( $\alpha-D$-glucopyranose) causes an approximate 31 fold increase in the solubility of biphenyl in aqueous medium and has best complementarity for naphthalene by forming 1:1 complex.
\end{abstract}

Keywords: Arenes, Amino glucose, Molecular tweezers, Scaffolds.

\section{Introduction}

Although, the modern field of molecular recognition began with Pederson's synthesis of crown ethers ${ }^{1}$, Emil Fisher used the analogy of a lock and key to describe the receptor-guest interaction ${ }^{2}$, more than a century ago. Later, the phenomenon of complex formation by organic molecules having an appropriate cavity to bind substrates was termed host-guest complexation by Cram ${ }^{3}$. For effective molecular recognition the host must provide a cavity that has molecular complementarity for the guest. Molecular tweezers ${ }^{4}$ sometimes referred to as molecular clips ${ }^{5}$, are non-cyclic molecular hosts with open cavity capable of binding guests. The guest is held / gripped by the two pincers of the host using non-covalent bonding interactions but is not completely encapsulated. The term 'receptor' has come to be used synonymously with 'host'

There are only few reports of water soluble molecular tweezers ${ }^{5-24}$ compared to otherwise reported molecular tweezers of variety of types, most of which are soluble in organic solvents. Water soluble molecular tweezers might be expected to complex a wide range of aromatic guests with the binding affinities dependent more on the extent of overlap 
between the host and the guest than on their electronic complementarity ${ }^{25}$. In particular, the hydrophobic effect in aqueous media can be very strong and can determine the stability of the associates to a substantial extent ${ }^{26}$.

This paper describes the synthesis of new 6-amino-6-deoxy- $D$-glucose derivatives as water soluble molecular tweezers and their use for the complexation of neutral arenes in aqueous medium. This type of studies have already been reported ${ }^{11}$ by the author elsewhere exploring $p$-substituted 6-O-phenyl ethers of glucose as acylic hosts. The present studies report that 6-amino-6-deoxy-D-glucose based water soluble hosts recognizes neutral apolar arenes in aqueous medium more effectively than water soluble hosts pertained to $p$-substituted 6- $O$ phenyl ethers of glucose ${ }^{11}$. It seems that $\mathrm{N}^{+}-\pi$ interactions, which were absent, in case of $p$ substituted 6- $O$-phenyl ethers of glucose based acylic hosts, also have some contribution for the complexation of present tweezers with neutral apolar arenes in aqueous medium.

\section{Experimental}

Melting points were determined in capillaries and are uncorrected. PMR and CMR spectra were recorded at $200 \mathrm{MHz}$ on a Bruker FT NMR 200 Spectrometer. PMR spectra at $60 \mathrm{MHz}$ were recorded on an JEOL JNM PMX 60 SI spectrometer. TMS was used as internal reference for solutions in deuteriochloroform. UV spectra were recorded with a Shimadzu UV-160 UVVIS spectrophotometer and value of $\varepsilon$ are in $\mathrm{cm}^{-1} / \mathrm{M}$. Optical rotations were measured with a JASCO DIP-360 digital polarimeter in a $1 \mathrm{dm}$ cell. Column chromatography was performed on silica gel (60 - 120 mesh) and TLC plates were coated with silica G. The spots were developed in iodine and /or charring with $1 \%$ sulfuric acid in water. Doubly distilled water and analytical grade $n$-hexane were used for spectroscopy. Distilled solvents were used for column chromatography. Other chemicals were of AR grade and used without further purification.

\section{Synthesis}

\section{5,6-Anhydro-1,2-O-isopropylidene- $\alpha$-D-glucofuranose (1)}

The compound was synthesized as described in literature ${ }^{27}$, m.p. $133^{\circ} \mathrm{C} ;[\alpha]_{\mathrm{D}}{ }^{27}-26.5^{\circ}$.

\section{4,4'-Methylenedianiline (2)}

The compound was prepared by the method given in literature ${ }^{28}$, m.p. $88-89{ }^{\circ} \mathrm{C} ;{ }^{1} \mathrm{H}$ NMR $\left(60 \mathrm{MHz}, \mathrm{CDCl}_{3}\right.$,): $\oint 3.15\left(\mathrm{~s}, 4 \mathrm{H}, \mathrm{NH}_{2}\right), 3.67\left(\mathrm{~s}, 2 \mathrm{H}, \mathrm{CH}_{2}\right), 6.45$ and 6.83 each $(\mathrm{AB} \mathrm{q}, 4 \mathrm{H}$, $\mathrm{J}=8.2 \mathrm{~Hz}, \mathrm{ArH})$.

\section{N,N'-Dimethyl-4,4'-methylenedianiline (3)}

The compound was synthesized by the method reported in literature ${ }^{29}$, m.p. $34-35{ }^{\circ} \mathrm{C} ;{ }^{1} \mathrm{H}$ NMR (60 MHz, $\mathrm{CDCl}_{3}$ ): $\delta 2.67\left(\mathrm{~s}, 6 \mathrm{H}, \mathrm{NCH}_{3}\right), 3.03$ (br, $\left.2 \mathrm{H}, \mathrm{NH}\right), 3.6\left(\mathrm{~s}, 2 \mathrm{H}, \mathrm{CH}_{2}\right), 6.20$ and 6.67 each $(\mathrm{AB} q, 4 \mathrm{H}, \mathrm{J}=8.0 \mathrm{~Hz}, \mathrm{ArH})$.

6-[4'-(p-Toluidine)anilino]-6-deoxy-1,2-O-isopropylidene- $\alpha$-D-glucofuranose $(2 a)$ and 6,6'-(4",4"'-methylenedianilino)bis(1,2-O-isopropylidene- $\alpha$-D-glucofuranose (2b)

A well grinded mixture of $2(990 \mathrm{mg}, 5 \mathrm{mM})$ and $\mathbf{1}(2.02 \mathrm{~g}, 10 \mathrm{mM})$ was heated at 120 $130{ }^{\circ} \mathrm{C}$ for $1 \mathrm{~h}$ without solvent. TLC (ethyl acetate) indicated the formation of two products. Purification of the residue by column chromatography with dichloromethane-ethyl acetate $(80: 20 \mathrm{v} / \mathrm{v})$ as the eluent afforded $2 \mathbf{a}(480 \mathrm{mg}, 24 \%)$ as syrup. $[\alpha]_{\mathrm{D}}{ }^{27}-13.5^{\circ}(\mathrm{c} 1.0, \mathrm{EtOH})$; UV (EtOH) $\lambda_{\max } \mathrm{nm}(\log \varepsilon) 465.0$ (2.09), 296.0 (3.61), 252.0 (4.34), 213.0 (4.21); ${ }^{1} \mathrm{H}$ NMR

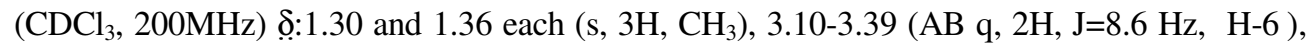
3.70 (br, 7H, $\mathrm{CH}_{2}(\mathrm{Ph})_{2}, \mathrm{NH}_{2}, \mathrm{OH}$ and $\left.\mathrm{NH}\right), 3.98$ (dd, 1H, H-5); 4.10 (br, 1H, H-4), 4.27 
(d,1H, J=2.2 Hz, H-3), 4.42 (d, 1H, J=3.6 Hz, H-2), 5.88 (d, 1H, J=3.6 Hz, H-1), 6.52-6.58 (AB q, 4H, J=8.2 Hz, 8.0 Hz, ArH), 6.89-6.96 (AB q, 4H, J=8.1 Hz, 8.0 Hz, ArH); ${ }^{13} \mathrm{C} \mathrm{NMR}$ $\left(\mathrm{CDCl}_{3}, 200 \mathrm{MHz}\right) \delta$ : 26.1 and 26.7 each $\left(1 \mathrm{C}, \mathrm{q}, \mathrm{CH}_{3}\right), 40.1\left(1 \mathrm{C}, \mathrm{t}, \mathrm{CH}_{2}(\mathrm{Ph})_{2}\right), 47.6(1 \mathrm{C}, \mathrm{t}$, C-6), 68.5 (1C, d, C-5), 75.2 ( 1C, d, C-3), 80.7 (1C, d, C-4), 85.1 (1C, d, C-2), 104.8 (1C, d, $\mathrm{C}-1), 111.7\left(1 \mathrm{C}, \mathrm{s}, \mathrm{OC}\left(\mathrm{CH}_{3}\right)_{2} \mathrm{O}\right), 113.9(2 \mathrm{C}, \mathrm{d}, \mathrm{Ar} \mathrm{C}$ ) $) 115.6(2 \mathrm{C}, \mathrm{d}, \mathrm{Ar} \mathrm{C} \mathrm{b}), 129.6(4 \mathrm{C}, \mathrm{d}$, $\left.\operatorname{Ar~} \mathrm{C}_{\mathrm{c}, \mathrm{c}^{\prime}}\right), 131.6\left(1 \mathrm{C}, \mathrm{s}, \mathrm{Ar} \mathrm{C}_{\mathrm{d}^{\prime}}\right), 132.3\left(1 \mathrm{C}, \mathrm{s}, \mathrm{Ar} \mathrm{C} \mathrm{d}_{\mathrm{d}}\right), 143.9\left(1 \mathrm{C}, \mathrm{s}, \mathrm{Ar} \mathrm{C}_{\mathrm{a}^{\prime}}\right), 145.9$ (1C, s, Ar $\mathrm{C}_{\mathrm{a}}$ ), Inept: $26.1,26.7,68.4,75.1,80.6,85.0,104.8,113.9,115.5,129.6$ (+ve), 40.1; 47.6 (ve); $\left(\mathrm{M}^{+}\right)$ion $m / z 400\left(\mathrm{M}^{+}\right) ; 198\left(\mathrm{M}^{+}-203\right.$ (sugar).

The second fraction on elution with dichloromethane-ethyl acetate $(50: 50 \mathrm{v} / \mathrm{v})$ gave the substrate $2 \mathbf{b}$ as a syrup ( $933 \mathrm{mg}, 31 \%) ;[\alpha]_{\mathrm{D}}{ }^{27}-17.4^{\circ}$ (c 1.0, EtOH); UV (EtOH) $\lambda_{\max } \mathrm{nm}$ $(\log \varepsilon) 250.0$ (4.53), 213.0 (4.39); ${ }^{1} \mathrm{H}$ NMR $\left(\mathrm{CDCl}_{3}, 200 \mathrm{MHz}\right) \delta: 1.30$ and 1.46 each $(\mathrm{s}, 6 \mathrm{H}$, $\mathrm{CH}_{3}$ ); 2.96 (br, 6H, OH and $\mathrm{NH}$ ), 3.39-3.70 (br m, 6H, $\mathrm{CH}_{2}(\mathrm{Ph})_{2}$ and $\left.\mathrm{H}-6\right), 3.98$ (dd, $2 \mathrm{H}, \mathrm{H}-$ 5), 4.10 (br, 2H, H-4), 4.27 (d, 2H, J=2.1 Hz, H-3), 4.42 (d, 1H, J=3.6 Hz, H-2), 5.90 (d, 2H, $\mathrm{J} 3.6 \mathrm{~Hz}, \mathrm{H}-1), 6.57$ and 6.94 each $(\mathrm{d}, 4 \mathrm{H}, \mathrm{J}=8.0, \mathrm{Ar} \mathrm{H}) ;{ }^{13} \mathrm{C} \mathrm{NMR}\left(\mathrm{CDCl}_{3}, 200 \mathrm{MHz}\right)$

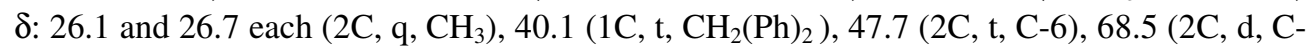
5), 75.2 (2C, d, C-3), 80.8 (2C, d, C-4), 85.1 (2C,d, C-2), 104.8 (2C, d, C-1), 111.8 (2C, s, $\left.\mathrm{OC}\left(\mathrm{CH}_{3}\right)_{2} \mathrm{O}\right), 114.0\left(4 \mathrm{C}, \mathrm{d}, \mathrm{Ar} \mathrm{C}_{\mathrm{b}}\right), 129.6(4 \mathrm{C}, \mathrm{d}, \mathrm{Ar} \mathrm{C}$, $), 132.0\left(2 \mathrm{C}, \mathrm{s}, \mathrm{Ar} \mathrm{C} \mathrm{C}_{\mathrm{d}}\right), 145.9(2 \mathrm{C}, \mathrm{s}$, Ar $\mathrm{C}_{\mathrm{a}}$ ); Inept: 26.1, 26.7, 68.4, 75.1, 80.8, 85.1, 104.8, 114.0, 129.6 (+ve), 40.1, 47.8 (-ve); $\left(\mathrm{M}^{+}\right)$ion $\mathrm{m} / \mathrm{z} 602\left(\mathrm{M}^{+}\right) ; 400$ (M-sugar); $385\left(400-\mathrm{CH}_{3}\right) ; 211\left(\mathrm{H}_{2} \mathrm{C}\left(\mathrm{C}_{6} \mathrm{H}_{4}\right)_{2}\left(\mathrm{NH}_{2}\right) \mathrm{NH}=\mathrm{CH}_{2}\right)$; 184 (211- $\left.\mathrm{NHCH}_{2}\right), 108(184-\mathrm{Ph})$.

6-Deoxy-6-[N-methyl(4'-N'-methyl(p-toluidine)](1,2-O-isopropylidene- $\alpha$-D-glucofuranose) (3a) and 6,6'-[N,N'-dimethyl-4",4"' -methylenedianilino)bis-(1,2-Oisopropylidene- $\alpha$-D-glucofuranose) (3b)

Compound $\mathbf{3}(1.13 \mathrm{~g}, 5 \mathrm{mM})$ was heated to $100{ }^{\circ} \mathrm{C}$ and to it was added compound $\mathbf{1}(2.02 \mathrm{~g}$, $10 \mathrm{mM})$. The temperature was raised to $120-125{ }^{\circ} \mathrm{C}$ and the reaction mixture aged for $1 \mathrm{~h}$ without solvent. TLC (ethyl acetate) indicated the formation of two products. Purification of the residue by column chromatography with dichloromethane-ethyl acetate $(50: 50 \mathrm{v} / \mathrm{v})$ as eluent afforded the substrate $\mathbf{3 b}(977 \mathrm{mg}, 31 \%)$ as colored syrup. UV (EtOH) $\lambda_{\max } \mathrm{nm}(\log \varepsilon)$ 307.4 (3.72), 263.8 (4.55), 213.2 (4.32); ${ }^{1} \mathrm{H} \mathrm{NMR}\left(\mathrm{CDCl}_{3}, 200 \mathrm{MHz}\right) \delta: 1.26$ and 1.44 each (s, $\left.6 \mathrm{H}, \mathrm{CH}_{3}\right), 2.87\left(\mathrm{~s}, 6 \mathrm{H}, \mathrm{NCH}_{3}\right), 3.29-3.51(\mathrm{AB} \mathrm{q}, 4 \mathrm{H}, \mathrm{H}-6) ; 3.73$ (br s, $6 \mathrm{H}, \mathrm{CH}_{2}$ and $\mathrm{OH}$ ), 3.95 (dd, 2H, J=2.4 Hz, H-5), 4.16 (br, 2H, H-4), 4.27 (s, 2H, H-3), 4.43 (d, 2H, J=3.4 Hz, $\mathrm{H}-2) ; 5.88(\mathrm{~d}, 2 \mathrm{H}, \mathrm{J}=3.4 \mathrm{~Hz}, \mathrm{H}-1), 6.69$ and 7.01each $(\mathrm{AB} \mathrm{q}, 4 \mathrm{H}, \mathrm{J}=8.2 \mathrm{~Hz}, \mathrm{ArH}) ;{ }^{13} \mathrm{C}$ NMR $\left(\mathrm{CDCl}_{3}, 200 \mathrm{MHz}\right) \delta$ : 26.0 and 26.6 each $\left(2 \mathrm{C}, \mathrm{q}, \mathrm{CH}_{3}\right), 39.8\left(1 \mathrm{C}, \mathrm{t}, \mathrm{CH}_{2}(\mathrm{Ph})_{2}\right), 40.0$ (2C, q, $\left.\mathrm{NCH}_{3}\right), 57.2$ (2C, t, C-6), 67.9 (2C, d, C-5), 75.0 (2C, d, C-3), 80.5 (2C, d, C-4), 84.9 $(2 \mathrm{C}, \mathrm{d}, \mathrm{C}-2), 104.7(2 \mathrm{C}, \mathrm{d}, \mathrm{C}-1), 111.5$ and 111.8 each $\left(2 \mathrm{C}, \mathrm{s}, \mathrm{OC}\left(\mathrm{CH}_{3}\right)_{2} \mathrm{O}\right), 113.6$ and 113.9each (4C, d, Ar $\left.\mathrm{C}_{\mathrm{b}, \mathrm{b}^{\circ}}\right), 129.4$ and 129.7 (4C, d, $\left.\mathrm{Ar} \mathrm{C}_{\mathrm{c}, \mathrm{c}^{\circ}}\right), 131.1$ and 131.4 each $(2 \mathrm{C}, \mathrm{s}, \mathrm{Ar}$ $\left.\mathrm{C}_{\mathrm{d}, \mathrm{d}^{\prime}}\right), 147.9\left(2 \mathrm{C}, \mathrm{s}, \mathrm{Ar} \mathrm{C}_{\mathrm{a}}\right)$; Inept: $26.1 ; 26.7 ; 39.9 ; 67.9 ; 74.9 ; 80.6 ; 85.0 ; 104.8 ; 113.8 ; 129.4$; 131.2; 147.9 (+ve); 40.0, 57.2 (-ve); $\left(\mathrm{M}^{+}\right)$ion $\mathrm{m} / 2631\left(\mathrm{M}^{+}\right) ; 630 ; 442,428$ ( $\mathrm{M}^{+}$-sugar).

The second fraction on elution with ethyl acetate gave the substrate $\mathbf{3 a}$ as colored syrup (578 mg, 27\%); UV (EtOH) $\lambda_{\max } \mathrm{nm}(\log \varepsilon) 302.6$ (3.64); $259.8(4.45) ; 213.2(4.21) ;{ }^{1} \mathrm{H}$ NMR $\left(\mathrm{CDCl}_{3}, 200 \mathrm{MHz}\right) \delta: 1.30$ and 1.48 each $\left(\mathrm{s}, 3 \mathrm{H}, \mathrm{CH}_{3}\right), 2.78\left(\mathrm{~s}, 3 \mathrm{H}, \mathrm{NHCH}_{3}\right), 2.88$ (s, $3 \mathrm{H}, \mathrm{NCH}_{3}$ ), 3.24 (br, 3H, OH and $\left.\mathrm{NH}\right), 3.36-3.53(\mathrm{AB} \mathrm{q}, 2 \mathrm{H}, \mathrm{H}-6), 3.77$ (s, $\left.2 \mathrm{H}, \mathrm{CH}_{2}(\mathrm{Ph})_{2}\right)$, 4.00 (dd, 1H, J=2.4 Hz, H-5), 4.22 (dd, 1H, H-4), 4.32 (d, 1H, H-3), 4.49 (d, 1H, J = 3.6 Hz, $\mathrm{H}-2), 5.94(\mathrm{~d}, 1 \mathrm{H}, \mathrm{J}=3.6 \mathrm{~Hz}, \mathrm{H}-1), 6.52(\mathrm{~d}, 2 \mathrm{H}, \mathrm{J}=8.4 \mathrm{~Hz}, \mathrm{ArH}), 6.75(\mathrm{~d}, 2 \mathrm{H}, \mathrm{J}=8.6 \mathrm{~Hz}$, $\mathrm{ArH}), 6.96-7.06(\mathrm{dd}, 4 \mathrm{H}, \mathrm{J}=8.6,8.4 \mathrm{~Hz}, \mathrm{Ar} \mathrm{H}) ;{ }^{13} \mathrm{C} \mathrm{NMR}\left(\mathrm{CDCl}_{3}, 200 \mathrm{MHz}\right) \delta: 26.2$ and 26.8 each $\left(1 \mathrm{C}, \mathrm{q}, \mathrm{CH}_{3}\right), 31.0\left(1 \mathrm{C}, \mathrm{q}, \mathrm{NHCH}_{3}\right), 40.0\left(2 \mathrm{C}, \mathrm{m}, \mathrm{NCH}_{3}\right.$ and $\left.\mathrm{CH}_{2}(\mathrm{Ph})_{2}\right), 57.3(1 \mathrm{C}$, t, C-6), 68.5 (1C, d, C-5), 75.5 ( 1C, d, C-3), 80.5 (1C, d, C-4), 85.2 (1C,d, C-2), 104.9 (1C, 
d, C-1), $111.7\left(1 \mathrm{C}, \mathrm{s}, \mathrm{OC}\left(\mathrm{CH}_{3}\right)_{2} \mathrm{O}\right), 112.7$ and 114.0 each (4C, d, $\left.\mathrm{Ar} \mathrm{C}_{\mathrm{b}}\right), 129.5$ (4C, d, $\mathrm{Ar}$ $\left.\mathrm{C}_{\mathrm{c},}\right), 130.7$ and 131.8 each $\left(2 \mathrm{C}, \mathrm{s}, \mathrm{Ar} \mathrm{C}_{\mathrm{d}}\right), 147.4$ and 148.2 each $\left(2 \mathrm{C}, \mathrm{s}, \mathrm{Ar} \mathrm{C}_{\mathrm{a}}\right)$; Inept: 26.1, 26.7, 31.0, 68.4, 75.4, 80.5, 85.1, 104.8, 112.7, 114.0, $129.5(+\mathrm{ve}), 40.0,57.2(-\mathrm{ve}) ;\left(\mathrm{M}^{+}\right)$ion $m / z, 429\left(\mathrm{M}^{+}\right) ; 428,414\left(\mathrm{M}^{+}-15\right), 413,239$.

\section{Water soluble molecular tweezers $2 \mathrm{c}, \mathbf{2 d}, \mathbf{3 c}$ and $\mathbf{3 d}$}

Compound 2a, 2b and 3a, 3b (500 mg) were taken in aqueous hydrochloric acid (20 mL, 1\%) and refluxed for 20 minutes. The solvent was removed on reduced pressure and residue showed a homogeneous spot on TLC plate. The water soluble products (2c, 2d, 3c and 3d) were further used without purification.

\section{Solubilization of neutral arenes in aqueous medium}

$10.0 \mathrm{~mL}$ of aqueous solution $\left(5 \mathrm{mM} \mathrm{L}^{-1}\right)$ of tweezer $(\mathbf{2 c}, \mathbf{2 d}, \mathbf{3 c}$ and $\mathbf{3 d})$ at $\mathrm{pH} 5$ was shaken with respective arene $(20 \mathrm{mg})$ for 20 minutes and filtered. The filtrate was extracted with $n$-hexane $(2 \times 25 \mathrm{~mL})$ and the arene concentration determined by UV VIS Spectrophotometer. Solubilities thus obtained were corrected for the solubility of the tweezer in $n$-hexane (tweezers $\mathbf{2 c}, \mathbf{2 d}, \mathbf{3 c}$ and $\mathbf{3 d}$ were found insoluble in n-hexane) and the stoichiometry of the tweezer-arene complex assigned. The solubilities of arenes in acidic aqueous medium without tweezer were determined in the same way.

\section{Results and Discussion}

Molecular tweezers synthesized and used for host-guest complexation studies are given in Figure 1. 4,4'-Methylenedianiline (2) and $N, N^{\prime}$-dimethyl-4,4'-methylenedianiline (3) were selected as building blocks for bent and hydrophobic part and appended at the para position with glucose moiety/ies to design the 'molecular tweezers'. The glucose moieties are expected to induce water solubility to these receptors and hydrophobic aromatic clefts would help complex non-polar guest molecules in aqueous medium.

The 'molecular tweezers' (2a, $\mathbf{2} \mathbf{b}, \mathbf{3 a}$ and $\mathbf{3 b}$ ) were prepared by dry heating of the appropriate amine and 5,6-anhydro-1,2- $O$-isopropylidene- $\alpha$ - $D$-glucofuranose $(\mathbf{1})$. These posses a tertiary amino group linked to $\mathrm{C}-6$ of the glucose moiety and their reducing function blocked in a cyclic acetal group. Opening of the oxirane ring of $\mathbf{1}$ by the various amines is expected ${ }^{30}$ to proceed by exclusive nucleophilic attack on C-6 and without inversion at C-5.

The NMR signal assignments were based on previous studies by Hall et $a l^{31}$ (for ${ }^{1} \mathrm{H}$ $\mathrm{NMR}$ ) and Vyas $e t a l^{32}$ (for ${ }^{13} \mathrm{C} \mathrm{NMR}$ ) on $O$-isopropylidene- $D$-hexoses. The chemical shifts

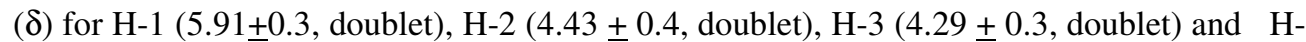
$5(3.98 \pm 0.3, s)$ were found constant and characteristic of these protons. The position of H-4 was also found constant, except in those cases where exact location could not be assigned because of overlapping signals. The most prominent shift was found in the H-6 signals. The methylene protons attached to aromatic moieties were found at $\delta 3.74 \pm 0.3$. The spectra for $\mathbf{2} \mathbf{a}$ and $\mathbf{2} \mathbf{b}$ are different for the aromatic region. In the former the signal corresponding to these protons were assigned at $\delta$ 6.53-6.58 and 6.89-6.96 as double doublets, whereas the later gave the same signals at $\delta 6.57$ and 6.94 as $\mathrm{AB}$ quartet. In a similar manner, the spectra for $3 \mathrm{a}$ showed aromatic signals at $\$ 6.52-6.75$ and $6.96-7.06$ as double doublets, whereas same signals for $\mathbf{3 b}$ were found at $\delta 6.69$ and 7.01 as AB quartet. The signal at $\delta$ 2.87-2.88 in tweezers $\mathbf{3 a}$ and $\mathbf{3 b}$ was assigned to methyl group attached to the tertiary nitrogen and the additional signal at $\delta 2.78$ for $\mathbf{3 a}$ was assigned to the methyl attached to the secondary nitrogen. 


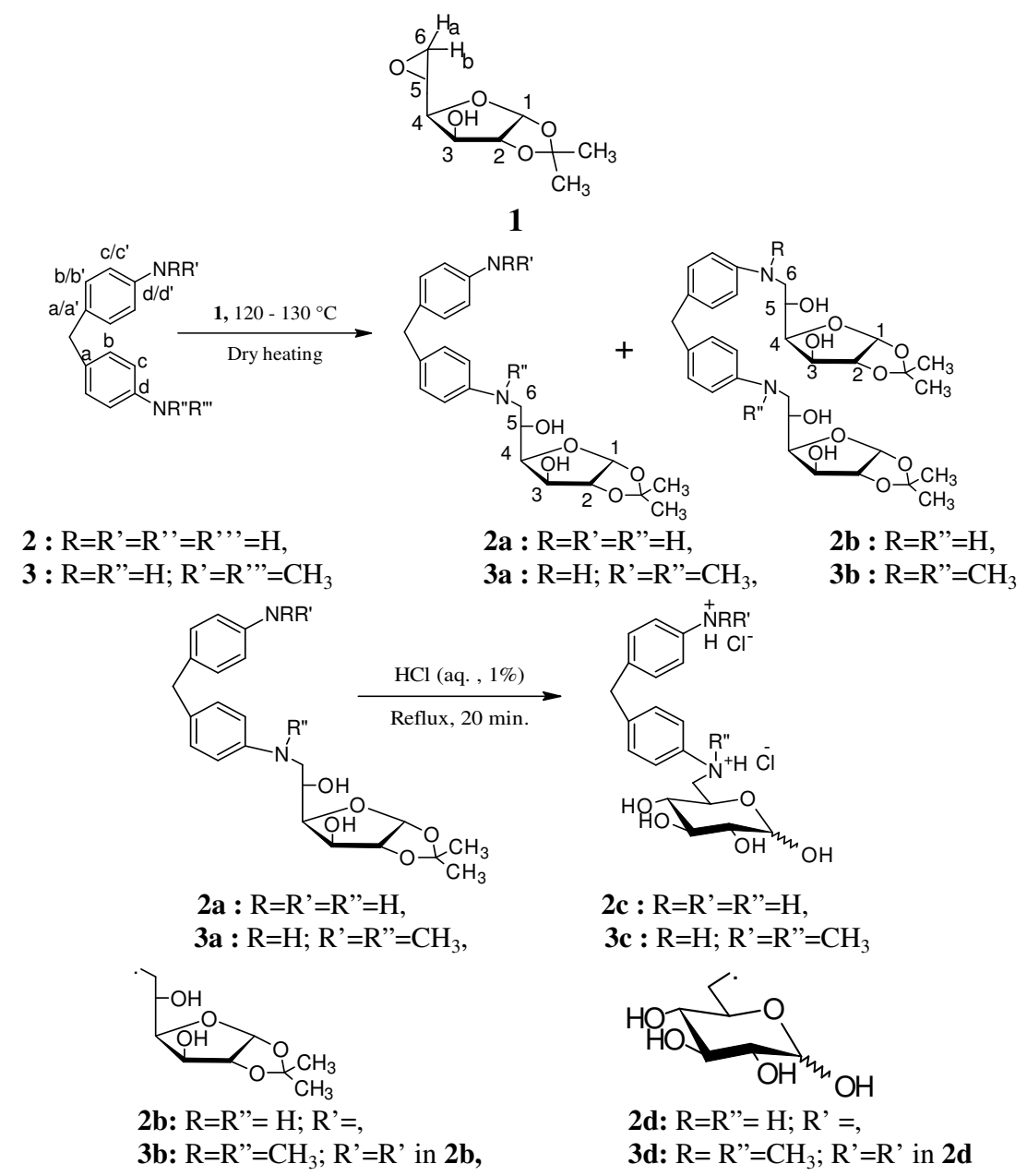

Figure 1. Structures of "Molecular tweezers" used in present studies

${ }^{13} \mathrm{C}$ NMR signal assignments of all the carbons in each entire molecule were supported by offresonance as well as by INEPT data. In the amino derivatives $\mathbf{2 a}, \mathbf{2 b}, \mathbf{3} \mathbf{a}$ and $\mathbf{3 b}$ the signals for the anomeric carbon, 1,3-dioxolane acetal carbon and methyl groups of the isopropylidene moiety were invariant at $(104.8 \pm 0.1),(111.6 \pm 0.2)$ and $(26.4 \pm 0.4)$, respectively. The chemical shifts $(\delta)$ for $\mathrm{C}$ $2(85.0 \pm 0.2)$ and $\mathrm{C}-3(75.3 \pm 0.2)$ were also found nearly identical. The methylene attached to aromatic moieties in these compounds was found constant at $\delta 40.0 \pm 0.1$. The aromatic carbons for 2a were assigned at $\delta 113.9,115.6,129.6,131.6,132.3,143.9$ and 145.5, whereas being symmetrically substituted 2b gave aromatic carbons at 114.0, 129.6, 132.0 and $145.9 \mathrm{ppm}$, respectively. In 3a and $\mathbf{3 b}$ signal at $\delta 40.0$ was assigned to methyl attached to tertiary nitrogen and additional signal at 31.0 in $\mathbf{3 a}$ was assigned to methyl attached to secondary nitrogen. The aromatic signals in 3b were found at 112.7, 114.0, 129.5, 130.7, 131.8, 147.4 and 148.2 respectively, whereas in 3a, these signals were assigned at 113.6, 113.9, 129.4, 129.7, 131.1, 131.4 and 147.9 respectively.

In mass spectra, for compounds $\mathbf{2 a}, \mathbf{2} \mathbf{b}, \mathbf{3 a}$ and $\mathbf{3 b}$, a peak corresponding to the complete elimination of entire sugar moiety was found. The abundant fragment of mass corresponding to imine formation ( $\mathrm{RR}^{\prime} \mathrm{N}=\mathrm{CH}_{2}$ ), after $\mathrm{C}-\mathrm{C}$ cleavage of $\mathrm{C}-6$ and $\mathrm{C}-5$ of sugar moiety was found for compounds $\mathbf{2} \mathbf{a}, \mathbf{2 b}$ and $\mathbf{3 b}$ respectively. 
'Molecular tweezers' 2a, 2b, 3a and $\mathbf{3 b}$ were deprotected of isopropylidene group by refluxing in $1 \%$ aqueous hydrochloric acid for $20 \mathrm{~min}$ to afford water soluble 'molecular tweezers' $\mathbf{2 c}, \mathbf{2 d}, \mathbf{3 c}$ and $\mathbf{3 d}$ which were used for solubilization of neutral arenes in aqueous medium.

\section{Solubilization of neutral arenes in aqueous medium}

Table 1 displays the results of solid -liquid extraction studies of some neutral arenes in aqueous medium in the absence and presence of water soluble molecular tweezers $\mathbf{2 c}, \mathbf{2 d}, \mathbf{3 c}$ and $3 \mathbf{d}$ respectively. The results clearly reveal the vitality of the hydrophobic cavity for the host-guest complexation in aqueous environment by diminishing the unfavorable contacts between water molecules and apolar arene guests.

Table 1. Solubility ratio (Solubility in water: in presence of tweezer in water) of arenes in aqueous medium $(\mathrm{pH}=5)$

\begin{tabular}{ccccccc}
\hline Entry & Naphthalene & Biphenyl & Durene & Fluorene & Anthracene & Phenanthrene \\
\hline 2c & $1: 7.7$ & $1: 11.1$ & $1: 1.1$ & $1: 5.0$ & $1: 2.0$ & $1: 2.8$ \\
2d & $1: 15.3$ & $1: 19.0$ & $1: 1.3$ & $1: 5.8$ & $1: 2.4$ & $1: 3.2$ \\
3c & $1: 17.1$ & $1: 11.5$ & $1: 1.3$ & $1: 4.8$ & $1: 2.0$ & $1: 1.8$ \\
3d & $1: 23.0$ & $1: 31.0$ & $1: 5.7$ & $1: 1.8$ & $1: 4.7$ & $1: 4.1$ \\
\hline
\end{tabular}

In all these studies the better affinity of tweezers (2d and $\mathbf{3 d}$ ) with two glucopyranose moieties compared with those having one sugar moiety (2c and 3c) suggested that increase in solubility was due to the increase in van der Waals interactions. The importance of these interactions has previously been recognized for the inclusion complexes formed by cyclodextrins ${ }^{33}$. Hydrophobic interactions are however indispensable and the main driving force for complexation of tweezers with neutral arene guests with some contribution through special $\mathrm{N}^{+}-\pi$ interactions.

Stoichiometric ratio of tweezer-arene complexes are documented in Table 2. It is found that naphthalene is most suitable for complementarity (1:1 complex) between host and guest being better recognized by the hydrophobic cavity. These liquid-extraction studies in aqueous medium for neutral apolar arenes as guests corroborate the use of synthesized water soluble tweezers $(\mathbf{2 c}, \mathbf{2 d}, \mathbf{3 c}$ and $\mathbf{3 d})$ as reverse phase transfer agents.

Table 2. Stoichiometric ratio (stoichiometry of tweezer: arene complex) ${ }^{* *}$

\begin{tabular}{|c|c|c|c|c|c|c|}
\hline Entry & Naphthalene & Biphenyl & Durene & Fluorene & Anthracene & Phenanthrene \\
\hline $2 c$ & $1: 0.35$ & $1: 0.015$ & 1:0.018 & $1: 0.053$ & - & - \\
\hline 2d & $1: 0.69$ & $1: 0.026$ & $1: 0.022$ & $1: 0.062$ & - & - \\
\hline $3 c$ & $1: 0.77$ & 1:0.016 & 1:0.022 & 1:0.051 & - & - \\
\hline 3d & $1: 1.03$ & $1: 0.042$ & 1:0.095 & 1:0.019 & - & - \\
\hline
\end{tabular}

\section{Conclusion}

The present investigation demonstrates the use of glucose based water soluble molecular tweezers as reverse phase transfer agents for complexation and thus solubilization of otherwise insoluble neutral arenes in aqueous medium. It was revealed that more is the hydrophilic:hydrophobic ratio for a particular set of tweezers (i.e. $\mathbf{2 c}, \mathbf{2 d}, \mathbf{3 c}$ and $\mathbf{3 d}$ ), more is the solubilization for arenes. It was also found that among all arene used for solubilization, biphenyl was better solubilized by the tweezers, in aqueous medium. In host-guest complexation studies, it was revealed that naphthalene is best recognized by all the guests especially by $\mathbf{3 d}$, which forms a (1:1) complex with it.

\section{Acknowledgment}

Financial support for this work from the Department of Science and Technology, Government of India, New Delhi is gratefully acknowledged. 


\section{References}

1. (a) Pedersen C J, J Am Chem Soc., 1967, 89, 2495; (b) Ibid, 1967, 89, 7017.

2. Fisher E, Berichte, 1894, 27, 2985-2993.

3. Cram D J and Cram J M, Sci., 1974, 183, 803-809.

4. Chen C W and Whitlock Jr H W, J Am Chem Soc., 1978, 100, 4921-4922.

5. Klärner F G and Kahlert B, Acc Chem Res., 2003, 36, 919-932.

6. Zimmerman S C, In Bioorganic Chemistry Frontiers, Springer-Verlag, Berlin / Heidelberg, 1992, 2, 35.

7. Scrimin P, Tecilla P, Tonellato, U and Vignaga N, J Chem Soc Chem Commun., 1991, 449-451.

8. Shimazawa R, Hashimoto Y and Iwasaki S, Tetrahedron Lett., 1992, 33, 7192.

9. Zimmerman S C, Topics in Current Chemistry series, Springer Berlin / Heidelberg. 1993, 165, 71.

10. Reek J N H, Kros A and Nolte R J M, Chem Commun., 1996, 245-247.

11. Sharma L, J Incl Phenom Macrocycl Chem., 1998, 31, 161.

12. Ohara Suguru, Ishihara Kazuaki and Yamamoto Hisashi, Nippon Kagakkai Koen Yokoshu (Jp.) 2001, 79, 1138.

13. Jasper C, Schrader T, Panitzky J and Klärner F G, Angew Chem Int Ed., 2002, 41, 1355-1358.

14. Fokkens M, Jasper C, Schrader T, Koziol F, Ochsenfeld C, Polkowska J, Lobert M, Kahlert B and Klärner F G, Chem Eur J., 2005, 11, 477-494.

15. Fokkens M, Schrader T and Klärner F G, J Am Chem Soc., 2005, 127, 14415-14421.

16. Huang H and Drueckhammer D G, Chem Commun., 2006, 2995-2997.

17. Klärner F G, Kahlert B, Nellesen A, Zienau J, Ochsenfeld C and Schrader T, J Am Chem Soc., 2006, 128(14), 4831-4841.

18. Villari V, Mineo P, Micali N, Angelini N, Vitalini D and Scamporrino E, Nanotechnology, 2007, 18, 375503.

19. Harmata M and Stork G, In Strategies and tactics in organic synthesis, Orlandotla T L (Ed.,) Academic Press: New York. 2008.

20. Talbiersky P, Bastkowski F, Klärner F G and Schrader T, J Am Chem Soc., 2008, 130, 9824-9828.

21. Mondragón K V and Morales H R, Chem Commun., 2009, 6726.

22. Polkowska J, Bastkowski F, Schrader T, Klärner F G, Zienau J, Koziol F and Ochsenfeld C, J Phys Org Chem., 2009, 22, 779-790.

23. Branchi B, Ceroni P, Balzani, V, Cartagena M C, Klärner F G, Schrader T and Vögtle F, New J Chem., 2009, 33, 397-407.

24. Gomes R, Parola J A, Bastkowski F, Polkowska J and Klärner F G, J Am Chem Soc., 2009, 131, 8922-8938.

25. Ferguson S B and Diederich F, Angew Chem., 1986, 98, 1127-1129.

26. Meyer E A, Castellano R K and Diederich F, Angew Chem Int Ed., 2003, 42, 1210-1250.

27. Ohle H and Vargha L v, Berichte., 1929, 62, 2435-2444.

28. King H, J Chem Soc Trans., 1920, 117, 988-992.

29. Braun J v, Berichte, 1908, 41, 2145.

30. Parker R E and Isaacs N S, Chem Rev., 1959, 59, 737.

31. Hall L D, Black S A, Slessor K N and Tracey A S, Can J Chem., 1972, 50, 1912.

32. Vyas D M, Jarrell H C and Szarek W A, Can J Chem., 1975, 53, 2748-2754.

33. Tabushi I, Kiyosuke Y, Sugimoto T and Yamamura K, J Am Chem Soc., 1978, 100, 916-919 


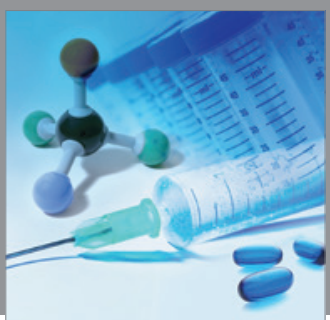

International Journal of

Medicinal Chemistry

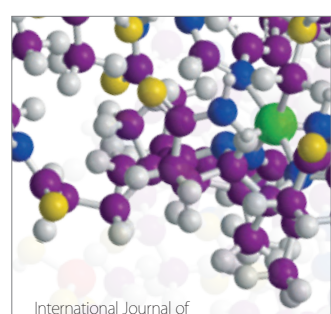

Carbohydrate Chemistry

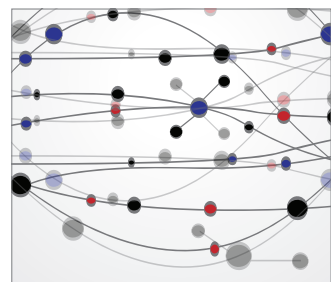

The Scientific World Journal
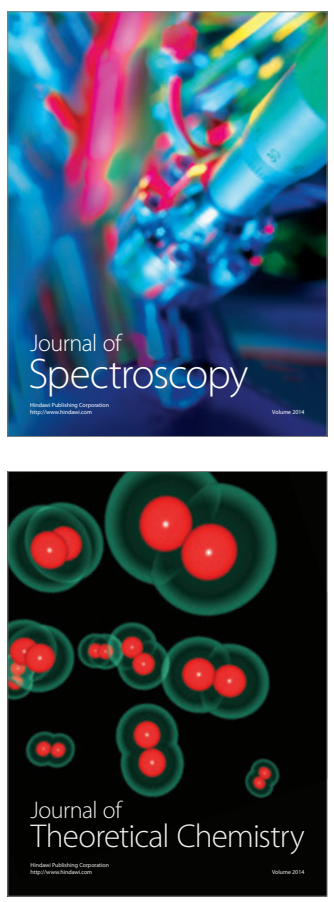
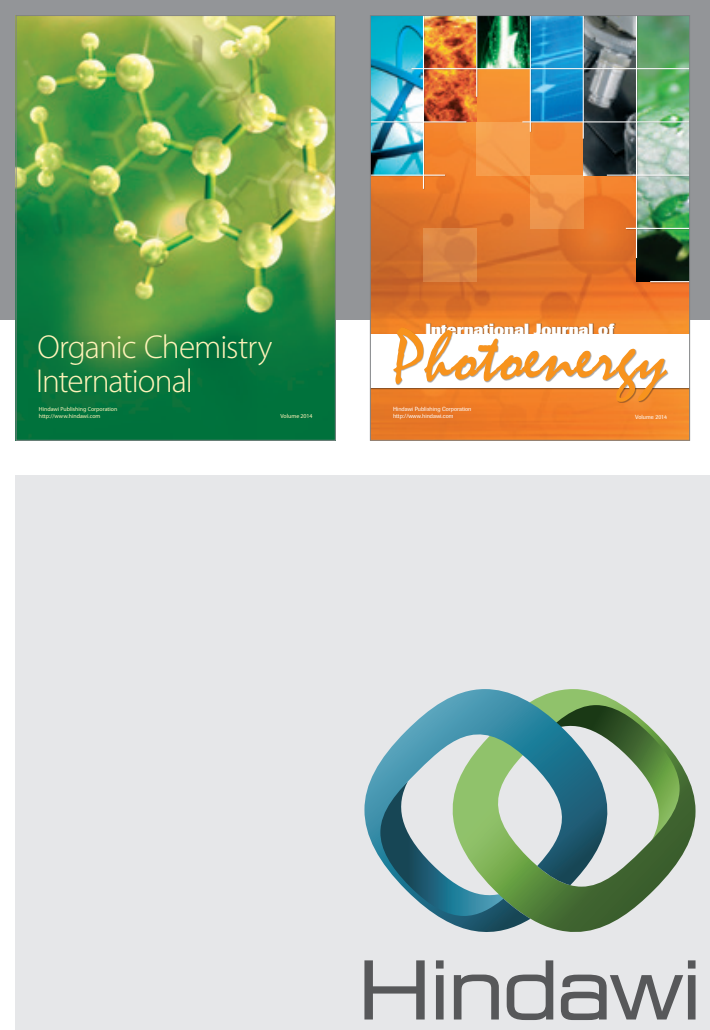

Submit your manuscripts at

http://www.hindawi.com
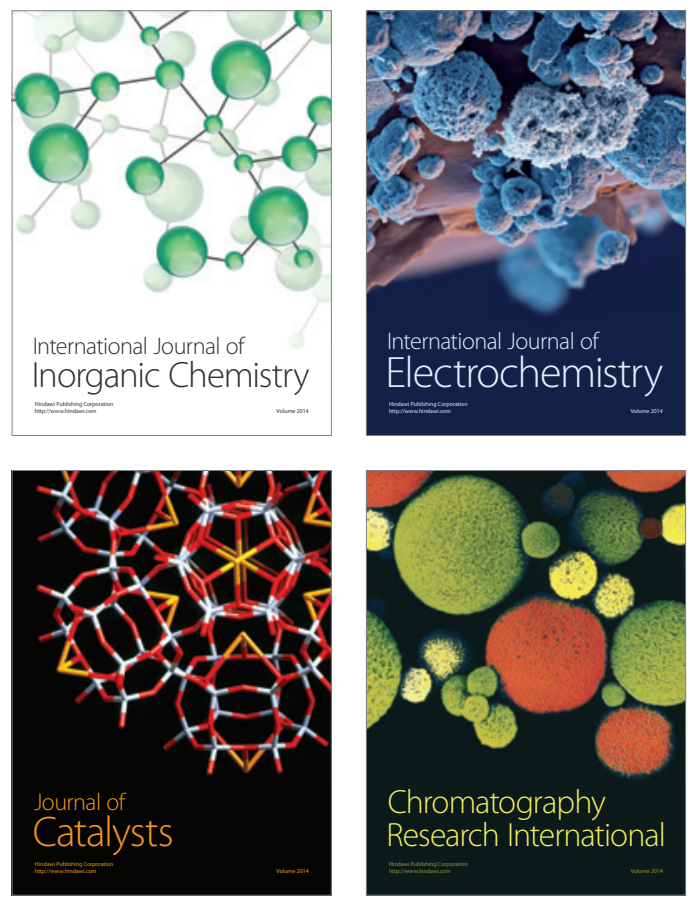
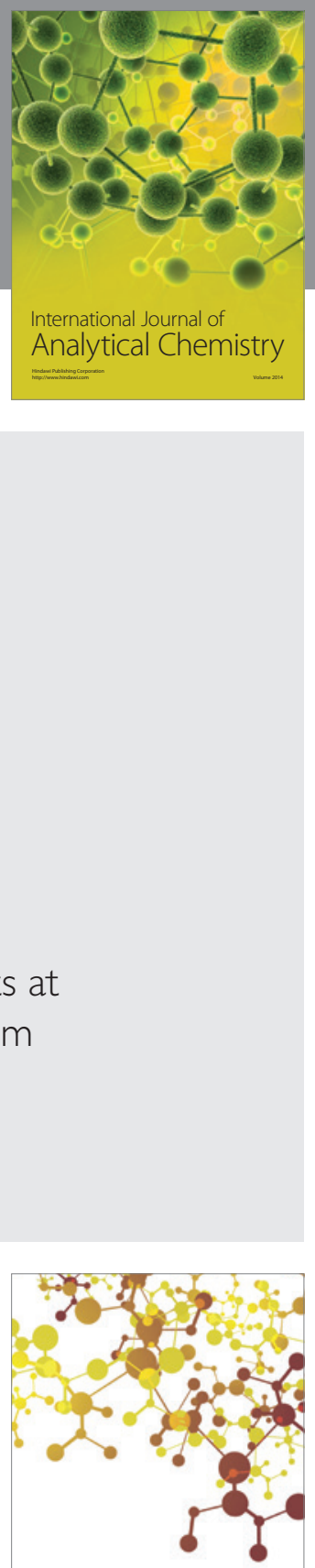

Journal of

Applied Chemistry
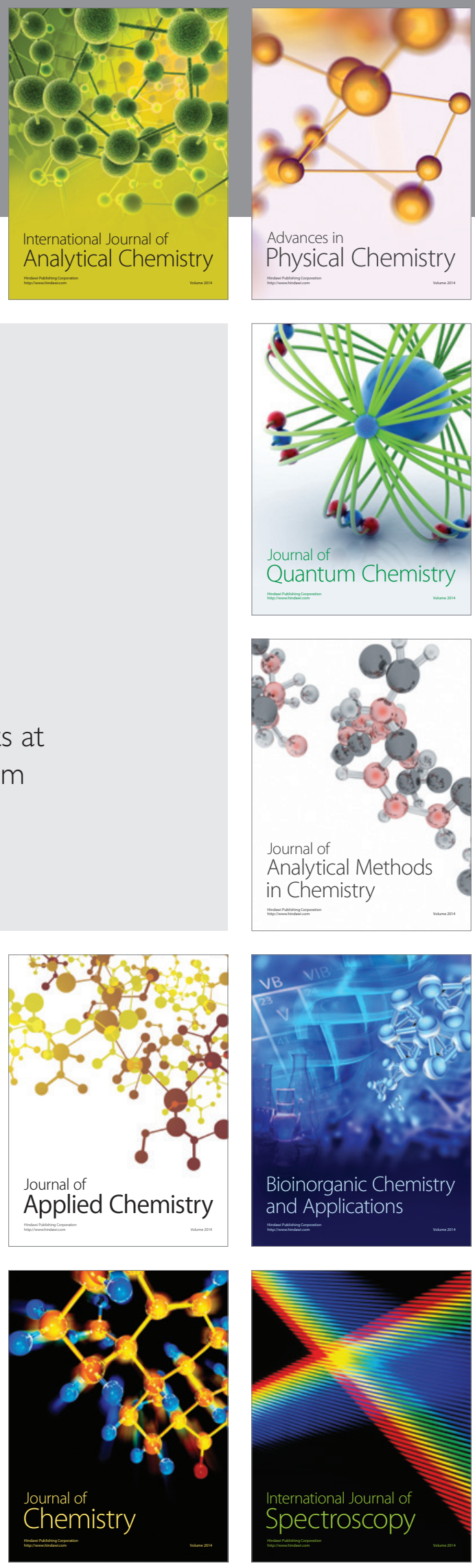